\title{
Teacher's Opinion Regarding Potential use and Misuse of Teachers' Evaluation in Undergraduate Dental Education
}

\author{
Dr. Md. Shoheilul Amin ${ }^{1}$, Professor Ismail Khan ${ }^{2}$, Professor Dr. Md. Humayun Kabir Talukder ${ }^{3}$, Dr. Jamil Ahsan Ansary ${ }^{4}$
}

\begin{abstract}
Teachers' evaluation in our country is yet to be started. But in many countries of the world it has been adopted a long time ago. It not only affects the teaching process but also motivate teachers for self-development. It is a series of activities and actions that are interconnected and relate to a specific purpose. In the last two decades, the importance of teaching evaluation has been emphasized in higher education. Many medical and dental schools have searched for ways to effectively and constructively evaluate performances of their faculty members. This cross-sectional descriptive study conducted among the teachers of public \& private dental colleges adopting convenience sampling. Study revealed that teacher evaluation can improve teacher's teaching ability $(94.1 \%)$, it can be used to assessing training need of the teacher $(94.1 \%)$, it can protect students from incompetent teachers $(91.2 \%)$, it can be used for promoting teachers $(91.2 \%)$, it can also help to monitor the performances of teacher by administrators $(88.2 \%)$, The most common sources of evaluation data have been students, peers, and teachers themselves. Teacher evaluation is often designed to serve two purposes- to measure teacher competence and to foster professional development and growth. A teacher evaluation system give teachers useful feedback on classroom needs, the opportunity to learn new teaching techniques, and counsel from principals and other teachers on how to make changes in their classrooms. The goal of any effective evaluation process must be growth of good teacher.
\end{abstract}

Key words -Dental Education, Teacher's Evaluation

\section{Introduction}

Medical and dental education system plays a fundamental role in enhancing health system improvement of any country. Teachers are the spine of an education system. Though teaching is a noble profession, teachers are professionals as any other and must be assessed by their performance and utility. ${ }^{1}$ It is a continuing process and it improves day by day and continuing dental education system we need good teachers and proper teachers' evaluation system. Enthusiastic and creative teachers convey ideas in clear and convincing ways, provide stimulating learning environments for different types of students, foster productive teacher-student relationships and work effectively with colleagues and parents. ${ }^{2}$. Teachers need feedback on their performance to help them to identify how to be better teachers and to improve their teaching practice. At the same time, teachers should be accountable for their performance and progress in their career on the basis of demonstrated effective teaching practice $^{3}$. The importance of teachers' quality in promoting the learning and raising the attainment of students have been demonstrated in many studies. The effective monitoring and evaluation of teaching is essential for the improvement of teaching in dental education. The teachers were evaluated on

\footnotetext{
1. Assistant Professor, Pioneer Dental College.

2. Ex-Principal Professor, Dhaka Medical College.

3. Professor, Curriculum development and Evaluation Center for Medical Education, Dhaka.

4. Assistant Professor, Pioneer Dental College.
}

Address of correspondence: Dr. Md. Shoheilul Amin,

Assistant professor, Pioneer Dental College, Dhaka.

Email-shahel.dr@gmail.com the basis of parameters such as the topics of teaching, capability of clarification, interest of teaching, contemporary knowledge on subject, regularity, voice, sincerity and punctuality for improving medical education. Till now no study has been conducted in the field of teachers' evaluation in dental education of Bangladesh. But it is essential to assess the strength of teachers and those aspects of their practices which could be further developed for improvement of their teaching. Teaching is too important which to be examined all the times. From this perspective, the development of teachers' evaluation in dental education of Bangladesh is a vital step to improve the effectiveness of teaching and learning and to improve the educational standards.

\section{Methodology}

This cross-sectional descriptive study was carried out among the teachers of one public dental college (Dhaka Dental College) and 2 private dental colleges (Pioneer Dental College and City Dental College) from 01.01.2011 to 30.12.2011 in Dhaka city. Data were collected by convenience sampling. A total of 51 teachers participated in the study among them 34 teacher by self-administered questionnaire and 17 in depth interview. All the answers were recorded by writing and checked at the end of the interview. The result of the answer of semi structured questionnaire by teachers' was analyzed by using SPSS soft ware package. All the instruments were developed and finalized after pretesting outside of the study area.

\section{Results}

The teachers' opinions regarding teacher evaluation were taken through in-depth interview of teachers of selected dental

Bangladesh Journal of Medical Education 2018;9(2):24-26. (C) 2018 Amin et al., publisher and licensee Association for Medical Education. This is an Open Access article which permits unrestricted non-commercial use, provided the original work is properly cited. 
colleges in Dhaka city. 51 teachers were participating in this study, out of them 34 teachers gave their opinion by structured questionnaire and 17 teachers gave their opinion through in-depth interview. Among them 2 were professors, 19 associate professors and 9 assistant professors and 4 lecturers.

Table 1: Distribution of the teachers by their institutes. $n=34$

\begin{tabular}{|l|c|c|}
\hline Name of the Institute & Frequency & Percent (\%) \\
\hline Pioneer Dental College & 15 & 44.1 \\
\hline City Dental College & 8 & 23.5 \\
\hline Dhaka Dental College & 11 & 32.4 \\
\hline Total & 34 & 100.0 \\
\hline
\end{tabular}

Table 1 Out of 34 teacher 15(44\%) from Pioneer dental College, 8 (23.5\%) from City Dental College,11(32.4\%) from Dhaka Dental College.

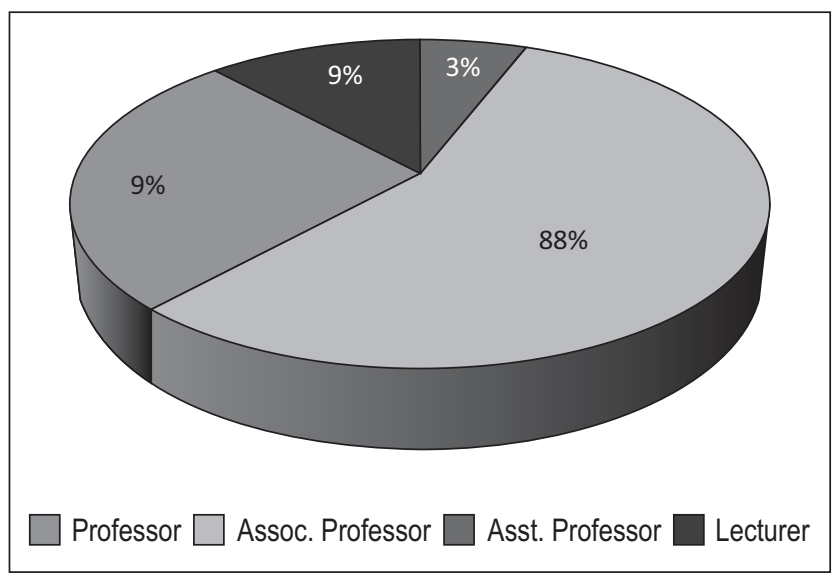

Graph 1: Distribution of the respondent teachers as per their designation.

Graph 1 Out of 34 respondents Professor was 2 (6\%), Associate Professor was 19 (56\%), Assistant Professors was $9(26 \%)$ and Lecturer was $4(12 \%)$.

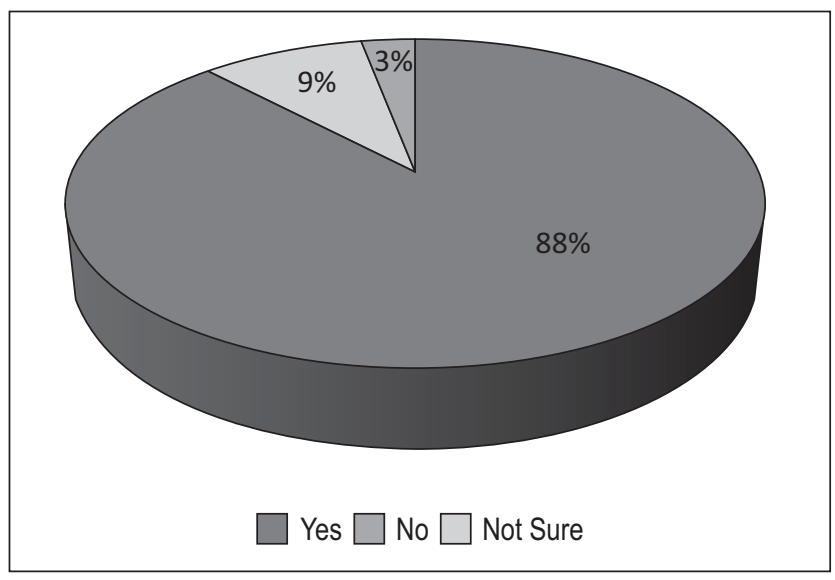

Graph 2: Distribution of teachers by their opinion regarding the necessity of teachers' evaluation in dental education.
Graph 2 have Shown that distribution of respondents regarding the necessity of teachers' evaluation in dental education .Out of 34 respondents, $30(88 \%)$ gave opinion in favor, $3(9 \%)$ were not sure and $1(3 \%)$ were not in favor of teacher evaluation.

Table 2: Distribution of the teachers by their opinion about different potential uses of teachers' evaluation

\begin{tabular}{|l|c|c|}
\hline $\begin{array}{l}\text { Potential uses of Teachers' } \\
\text { Evaluation }\end{array}$ & Frequency & Percent (\%) \\
\hline $\begin{array}{l}\text { Teacher evaluation can improve } \\
\text { teacher' teaching ability. }\end{array}$ & 32 & 94.1 \\
\hline $\begin{array}{l}\text { It can protect students from } \\
\text { incompetent teachers. }\end{array}$ & 31 & 91.2 \\
\hline $\begin{array}{l}\text { It can help to monitor the } \\
\text { performances of teacher by } \\
\text { administrators. }\end{array}$ & 30 & 88.2 \\
\hline $\begin{array}{l}\text { Teacher evaluation can be used to } \\
\text { assess training need of the teacher. }\end{array}$ & 32 & 94.1 \\
\hline $\begin{array}{l}\text { It can help to advice the } \\
\text { subordinate teacher by authorities }\end{array}$ & 29 & 85.3 \\
\hline $\begin{array}{l}\text { It can be used for promoting } \\
\text { teachers. }\end{array}$ & 31 & 91.2 \\
\hline $\begin{array}{l}\text { It can be used to decide increase } \\
\text { pay and bonus for the teacher. }\end{array}$ & 33 & 97.1 \\
\hline $\begin{array}{l}\text { It can be used for retention/ } \\
\text { renewal decision for teacher. }\end{array}$ & 24 & 70.6 \\
\hline $\begin{array}{l}\text { It can be used for dismissal/ } \\
\text { termination/transfer of teachers } \\
\text { from teaching profession. }\end{array}$ & 29 & 85.3 \\
\hline $\begin{array}{l}\text { Results of it can be used for } \\
\text { teacher's self-development. }\end{array}$ & 29 & 76.5 \\
\hline $\begin{array}{l}\text { It can increase transparency of the } \\
\text { assigned organizations. }\end{array}$ & 26.3 \\
\hline Others & & \\
\hline
\end{tabular}

The teachers opinion about the potential uses of teachers' evaluation reveals that Most of the respondents gave opinion about teacher evaluation can be used to decide increase pay and bonus for the teacher (97.1\%). They also mentioned that it can improve teacher's teaching ability (94.1\%), teacher evaluation can be used to assessing training need of the teacher $(94.1 \%)$, it can protect students from incompetent teachers $(91.2 \%)$, it can be used for promoting teachers $(91.2 \%)$, it can help to monitor the performances of teacher by administrators $(88.2 \%)$, it can help to advice the subordinate teacher by authorities $(85.3 \%)$, it can be used for dismissal/termination of teachers from teaching profession( $85.3 \%$ ),results of it can be used for teacher's selfdevelopment $(85.3 \%)$, it can increase transparency of the assigned organizations

(76.5\%), it can be used for retention /renewal decision for teacher $(70.6 \%)$, others opinion like sponsors of different seminars fees $(5.9 \%)$.

Bangladesh Journal of Medical Education 2018;9(2):24-26. 
Table 3: Distribution of the teachers by their opinion about different potential misuses of teachers' evaluation

\begin{tabular}{|l|c|c|}
\hline $\begin{array}{l}\text { Potential Misuse of Teachers' } \\
\text { Evaluation }\end{array}$ & Frequency & Percent (\%) \\
\hline $\begin{array}{l}\text { It may create unhealthy } \\
\text { competition among teachers }\end{array}$ & 33 & 97.1 \\
\hline $\begin{array}{l}\text { It may hamper friendly } \\
\text { environment in the institutes }\end{array}$ & 33 & 97.1 \\
\hline $\begin{array}{l}\text { Teacher will try to satisfy the } \\
\text { evaluator or bosses rather than } \\
\text { concentrating on teaching }\end{array}$ & 30 & 88.2 \\
\hline $\begin{array}{l}\text { Unfairness may hamper } \\
\text { implementing effective teacher } \\
\text { evaluation }\end{array}$ & 33 & 97.1 \\
\hline $\begin{array}{l}\text { Some teachers will be rated as good } \\
\text { who ensure easy passing of student } \\
\text { rather than facilitate deep learning }\end{array}$ & 19 & 55.9 \\
\hline It will not be cost effective & & \\
\hline
\end{tabular}

Teacher's views about potential misuse of teachers' evaluations are most of the teachers agreed about that it may create unhealthy competition among teachers $(97.1 \%)$, it may hamper friendly environment in the institutes (97.1\%), teacher will try to satisfy the evaluator or bosses rather than concentrating on teaching (94.1\%), some teachers will be rated as good who ensure easy passing of student rather than facilitate deep learning $(97.1 \%)$, other opinion are unfairness may hamper implementing effective teacher evaluation.(88.2\%), it will not be cost effective( $55.9 \%$ ).

\section{Discussion}

The study explores the views of teacher about potential uses and misuses of teacher's evaluation in undergraduate dental education. It is apparent that most of the teachers noted that the potential use of teachers' evaluation lies in the fact that it will help to improve teacher's teaching ability and can be used to assess training need of the teachers ${ }^{4}$. It also can be used to decide to increase pay and bonus for the teacher. It can be used for promotion of teachers. In case of in-depth interview majority of the teachers gave their opinion about potential uses of teachers' evaluation are that it will help to improves teaching ability. But the general purpose of teacher evaluation is to safeguard and improve the quality of instruction received by students. Donald Medley described uses of formal teacher evaluation as (1) The Search for Great Teachers. (2) Inferring Teacher Quality from Student Learning; and (3) Examining Teaching Performance 5 .
In every work there are some drawbacks. Teacher evaluation is no exception. Over the time it could be corrected and the evaluation process will be more effective gradually ${ }^{6}$. In case of our country facts is that teacher's evaluation may create unhealthy competition among teachers. It may hamper friendly environment in the institutes and teacher will try to satisfy the evaluators or bosses rather than concentrating on teaching. Regarding the criteria for teachers' evaluation almost everyone mentioned that teachers' classroom performance can be the first. Some of the teachers also mentioned that, teachers' research work and relationship with student can be major issue in teachers' evaluation.

\section{Conclusion}

Teacher's evaluation in undergraduate dental education can improve teaching ability and protect students from incompetent teachers. But it should be implement by the help of proper guideline and evaluation policy. It can be said that without teacher evaluation there is no way for quality improvement of teacher in undergraduate dental education.

\section{References}

1. Farida Virani A Performance Evaluation Model for School Teachers: An Indian Perspective ,Second 21st Century Academic Forum Boston, USA at Harvard2015, Vol. 5, No. 1, ISSN: 2330-1236 Page-495-506

2. Linda S,Susan et al. A review of the evaluation of clinical teaching: new perspectives and challenges. Medical education 2000; 34:862-870

3. Nahar S. Evaluation of medical teachers and traditional teaching in pharmacology. Bangladesh J Pharmacol. 2006; Volume 1:Page 33-34.

4. Brandt. R. (1996), On a new direction for teacher evaluation, A conversation with Tom McGreal. Educational Leadership; 53(6), 30-33.

5 Donald Medley, Homer Coker, and Robert Soar (1984), The modern history of formal teacher evaluation. Volume-1,Page-14

6. Beall, J. On evaluation and professional development. Independent School Journal ;vol-59 Page 72-79. 